\title{
Journalist Independence as the Supervisor of 2018 Regional Election in Central Java
}

\author{
Alkomari \\ Faculty of Social and Political Science \\ Diponegoro University \\ Semarang, Indonesia \\ komarisindo@gmail.com
}

\begin{abstract}
Journalist independence is doubtful when entering the political year like 2018 Election. Along with this situation Press Council affirms the role of press to ensure the press independence and to fulfill the right of people to obtain quality and fair information. This research focuses on the journalist who becomes the supervisor of 2018 Regional Election at Central Java. The supervisor (Panwas) is required to be neutral in supporting the election. The research problem is how the journalists who become the supervisors keep their independence in journalism activities. The research was conducted by constructivist paradigm, using qualitative descriptive approach. The researcher explored deep phenomena and described the obtained results from the field, by conducting interview to the journalists who become supervisor of 2018 Regional Election at Central Java. This study used the theory of social construction. This research used the theory of Social Construction of Reality introduced by Peter L. Berger and Thomas Luckman that stated reality was the result of social construction. The results of this study state that the journalists who become the supervisor of 2018 Regional Election at Central Java remain neutral and nonaligned to any political interests. The action is conducted through limited news making and coverage that do not cover any political, legal, governmental and political affairs.
\end{abstract}

Keywords—independence; journalist; news

\section{INTRODUCTION}

Journalists have the duties to search, process, and deliver the information based on the truth in the community. The information is in the form of objective and independent news. Independence according to KBBI 2008 edition is a state that does not depend on others, not independent, not under the power or effect of other countries.

Bill Kovach and Tom Rosenstiel urge there are nine elements of journalism. It is mentioned in the fourth element that journalists must become independent when they cover news from particular party. So, the spirit and mind to be independent are more important than neutrality. However, journalists who give their opinion are required to keep their data accuracy. They must continue to verify, serve the community interests, and comply with various provisions that should be obeyed by a journalist. Being neutral is not a fundamental principle of journalism. Impartiality is not objectivity either. Principally, journalists should be independent in performing their coverage. [1, p. 119].

Independence is the hardest thing to be kept when someone deals with a particular party who has an interest and emotionally becomes the part of it. Any view can be biased and then no longer objective. [2, p. 25].

To ensure the press independence and to fulfill the right of public to obtain correct information, Indonesian journalists establish and obey the Journalist Code of Ethics (KEJ) that stated through the Decree of Press Council Number 03/SKDP/III2006 on Journalist Code of Ethics. Article 1 of KEJ explaining that Indonesian Journalist is independent, making the accurate and balanced news, and does not have bad intention. It is mentioned that independent is providing events or facts according to the reality without any interference, coercion, and intervention from other parties even the press companies' owner. Accurate means believed to be true according to the objective state when the events occur. Balance means all parties have equal opportunity and no bad intention means there is no intention to harm others purposely.

Based on the data from Press Council, throughout 2017 there are 698 complaints related to the press cases. From those numbers, 437 are directly reported and 261 are indirectly reported. The number is significantly increased compared to 2016 with 523 cases. From 698 cases in 2017, the complaint is mostly addressed to the journalists from printed media by 290 cases. Then followed by online media journalists who get complained during 2017.

In the current political year, the journalists' independence in delivering the information is often affected by the political interests of political parties, regional heads candidates, as well as political figures. Along with the political year in which there are two events namely Regional Election (Pilkada) and General Election (Pileg), journalists' independence becomes a very disruptive betting objectivity of news product. The effect is a news product created by journalists prone to favor one political interest, while the public interest is no longer a major concern. 
The phenomenon of journalists involved in political such as being a candidate campaign team or even a prospective candidate is now being faced by the media. Based on that problem, Press Council issues a circular on the position of journalists and media impartiality during the political year on January 12, 2018. In the circular mentioned that journalists who become members of the candidate's campaign team, become candidates, become legislative candidates (legislative candidates) are required to resign as journalists. In addition, if they continue to run the profession as journalists, it will disturb the independence and objectivity in the news.

This research is conducted to find how journalists keep the independence and objectivity of their reporting in this political year, but it is not directed to the journalists who become member of candidates' campaign team, become candidates or legislative candidates, but journalists who become part of election organizers, mainly Supervisory Committee (Panwas). Therefore, the main focus is the journalists who perform journalistic activities and concurrently become Supervisory Committee (Panwas).

The journalists involved in the board of election organizer supervise such as Supervisory Committee (Panwas) are increasing in the past 10 years. Even in 2018, number of journalists who become election organizers are increasing more and more. In addition, this is the research background to discover how the journalist who doubles to be Supervisory Committee (Panwas) keeps their independence in performing their profession as journalist.

There are seven journalists who double their duty and become Supervisory Committee (Panwas) at Central Java, in 2018. However, this research is more focused on the journalists' independence who double their profession as Supervisory Committee (Panwas). Besides, journalist's independence becomes the main focus for Press Council in every political event both regional and general election (Pileg).

The duties of journalist and Supervisory Committee (Panwas) are virtually the same since both providing supervision on Regional Election (Pilkada) and General Election (Pemilu). As a journalist, the duty of supervising is conducted by delivering the information that is deemed to deviate from the rules or provisions to the wider community through their respective media. As a part of the media, journalists have a role in providing political education for the community or voters. While as Supervisory Committee (Panwas), journalist is in charge of supervising to make a report on the stages of election by General Elections Commission (KPU) and the ad-hoc board in the sub-districts to village level.

Problems related to the administration and other issues will be resolved by Supervisory Committee collaborate with General Election Commission (KPU). Besides, in every case handling case there must be exist sanctions in the form of reprimand and dismissal. However, for the problems in the realm of law are solved through Supervisory Committee (Panwas) and Gakumundu (Integrated Law Enforcement) in which there are the elements of law enforcement such as police and prosecutors.
In addition, although the duties are providing supervision, but in running the profession of journalists they cannot become independent when delivering the information in a news product through the media. It is due to the journalist often directly or indirectly deal with the politicians including the supervised candidates. Related to the duty of journalism as Supervisory Committee (Panwas), the journalism products made by journalists who double their duties will be vulnerable to the alignment of certain political groups.

The journalist's relationship with any politician figures who become their respective interviewees before Regional Election (Pilkada) and General Election (Pemilu) become a problem for journalists in keeping their independence when making news as Supervisory Committee (Panwas). In addition, it is also difficult to keep journalist's independence who double their duties as Supervisory Committee (Panwas) when reporting the election issues that are involving the politicians, where the politician still has kinship with them.

\section{RESEARCH PROBLEM}

Journalists have a duty to deliver the information in the form of news product through the media for the benefit of public. In conducting their duties, journalists are required to maintain the independence on any made and delivered news through the media. Related to that issues, journalist who double their duty as Supervisory Committee (Panwas) is also in charge of supervising the implementation of Regional Election (Pilkada) and General Election (Pemilu) to run well according to the existing regulations.

Journalists who double their duties as Supervisory Committee (Panwas) facing problems that threat their independence to their news product. Besides, the political interests, the closeness of journalist relationship with any politicians include the candidates, the politicians and the prospective candidates or relative are becoming challenge that can interfere the journalist's independence. Due to that issue, this research is conducted by focusing on how the journalists who doubles their duties as Supervisory Committee (Panwas) remain independent in conducting the duties.

\section{RESEARCH OBJECTIVE}

This study aims to find how the journalist who doubles their duties as Supervisory Committee (Panwas) remain independent in performing their duties.

\section{RESEARCH METHODS}

Paradigm was a way of looking to understand the complexities of the real world. It was deeply embedded in its adherents and practitioners. Paradigm indicated what's important, legitimate, and sensible to them. Paradigms were also normative, pointing out to the practitioners what to do without the need for long existential or epistemological considerations [3]. 
The used paradigm in this research was constructivist paradigm. Constructivist paradigm was the paradigm that became the notion antithesis that laid the observation and objectivity in finding a reality or science. This paradigm viewed social science as a systematic analysis of socially meaningful action through direct and detail observation of the concerned social behaviors by creating and maintaining or managing their social world [4].

According to Patton, constructivist researchers studied the diverse realities constructed by individuals and the implications of that construction for their lives with others. In constructivist, each individual had a unique experience. Therefore, the research with this strategy suggested, every individual's way of looking at the world was valid, and they needed to appreciate that view.

Constructivist paradigm had several criteria that distinguished it from other paradigms, namely ontology, epistemology, and methodology. In ontology, the constructivist paradigm viewed reality as exist thing and plural, yet the meaning was different for each person. In epistemology, the researcher used a subjective approach because it could describe the construction of meaning by the individual. In methodology, this paradigm used various types of constructions and combined them in a consensus.

This process involved two aspects: hermeneutics and dialectics. Hermeneutics was an activity in summarizing text conversation, writing or picture. While dialectics was the use of dialogue as an approach so that the studied subjects could be reviewed and compared to the researcher's way of thinking. So that, the communication and interaction harmonics can be achieved [4].

This study used a qualitative approach that was allowing the researchers to explain a phenomenon holistically using words, regardless of number. According to Bodgan and Taylor cited by Lexy J. Moleong, qualitative methodology was a research procedure that produced a descriptive data in the form of written or oral words of observed people and behavior. This approach was directed to the background and the individual holistically (whole). So, it should not isolate individual or organization into variable or hypothesis, but it was needed to view them as part of a whole [5].

The qualitative approach emphasized the meaning, reasoning, definitions of a particular situation (in some contexts), more research on the issues related to the daily life. A qualitative approach was more emphasizing the process than the result. This research selected journalists who concurrently Supervisory Committee (Panwas) at regency or city level in Central Java as the research object. To answer the research objective, the researchers conducted several ways in collecting data such as observation or field observation and interviews with journalists who became Supervisory Committee (Panwas).

\section{THEORETICAL FRAMEWORK}

This study uses Social Construction of Reality which is introduced by Peter L. Berger and Thomas Luckman through their book The Social Construction of Reality: A Treatise in the Sociological of Knowledge. He explains the social process through its actions and interactions, in which the individual creates a continuously shared reality subjectively. In philosophy, the idea of constructivism has emerged since Socrates discovered the soul in human body, since Plato discovered reason and idea. The idea became even more concrete after Aristotle introduced the terms of, information, relationship, individual, substance, material, essence and so on. He said that, human are social beings, every statement must be verified, yet the key of knowledge is the logic and knowledge basic is fact. [6, p. 13].

Berger and Luckman [6, p. 14] explain social reality by separating the understanding of 'reality and knowledge'. Reality is defined as the quality contained in realities that are recognized as having independent existence of our own will. Knowledge is defined as the assurance that realities are real and have specific characteristics.

Berger and Luckman [6, p. 15] urge there is a dialectics both in individual creates the society and society creates individual. This dialectical process occurs through externalization, objectification, and internalization. The dialectical process has three stages.

First, externalization, this is self-expression into the world, both in mental and physical activity. This becomes the nature of human, who will always devote themselves to somewhere they belong. Human beings cannot be understood as being closed from the outside world. Human seeks to capture themselves, in other word human find themselves in this process.

Second, objectification, this is the achieved result both mentally and physically from the activity of human externalization. The result produces an objective reality that may confront the producer themselves as the outside fact and different from the human who produces it. Through this process of objectification, society becomes a reality of sui generis.

The result of that cultural externalization, for example, human creates a tool for the convenience of their life or nonmaterial culture in the form of language. Both the tool and the language are the activities of human externalization when dealing with the world, it is the result of human activities. Once produced, either objects or languages as externalization products become the objective reality. In fact, it can face humans as a producer of cultural products. Culture that have status as objective reality, exists outside the human consciousness, exists "there" for everyone. The objective reality is different from the individual subjective reality. It becomes an empirical reality that can be experienced by every

Third, internalization. The process of internalization is the re-absorption of the objective world into consciousness so that the individual subjective is affected by the structure of social world. The various elements of the objectified world will be 
caught as a symptom of reality beyond its consciousness, as well as an internal symptom of consciousness. Through internalization, human becomes the result of society.

For Berger, reality is neither scientifically formed nor something that God has sent down. But instead, it shaped and constructed. By this understanding reality has a double/plural face. Each person can have a different construction of a reality. Any person who has particular experience, preference, education, or social environment will interpret the social reality using their own construction.

\section{DISCUSSION}

The task of journalists and Supervisory Committee (Panwas) actually have a common that is conducting supervision. As a journalist, supervision is conducted on anything related to the interests of general public. While Supervisory Committee (Panwas) has the duty to supervise the election process stages, whether it is Regional Election (Pilkada) or General Election (Pileg). Journalists and Supervisory Committee (Panwas) in conducting their duties should be independent. In conducting their duties, journalist is responsible to the reader and the public. Meanwhile, Supervisory Committee (Panwas) in conducting their duties is responsible to the state because it is bound by the oath of office.

Although the duties have some similarities, yet journalist who doubles their duty and becomes supervisory Committee (Panwas) realizes that there are many conflicts of interest regarding to the political interests in conducting the work process of journalism. Along with the duty as Supervisory Committee (Panwas), the news product made by journalists may not become independent.

The researchers have observed the journalists who concurrently become Supervisory Committee (Panwas) in the district or city level at Central Java in 2018 Regional Election. Some of these journalists become Chairman of Supervisory Committee (Panwas), and the others become member of local Supervisory Committee (Panwas). Almost all journalists who serve as Supervisory Committee (Panwas) serve as journalists as well by conducting the process of journalism every day. They are tied up with the media company, although they also tied to the supervisory institution at the same time as Supervisory Committee (Panwas).

The journalist who concurrently becomes Supervisory Committee (Panwas) has its own limitation in keeping their independence and objectivity of the made news. For example, Habib Soleh, Journalist of Harian Umum Suara Merdeka who becomes the chairman of Magelang Regency Supervisory Committee (Panwas). Based on the researcher's interview on Habib Soleh, the limitation in conducting his journalism duty is, he is no longer performing journalism report related to the election either Regional Election (Pilkada) or General Election (Pileg). Journalism activities are still being undertaken on social activities such as natural disasters, arts, and culture. In addition, for the news of politics is conducting by other teammates in one respective media.
In addition, the quantity or amount of made news in each day is reduced. For example, before becoming Supervisory Committee (Panwas) he can make as many as 3-4 news per day, currently he reduces to only one news every day. The news is made in the evening by phone interview. It is due to his duty as Supervisory Committee (Panwas) that is starting from the morning until the afternoon. The restriction of news coverage and teammates are conducted by the journalist itself, without any command or direction from their respective media company.

The further limitation in journalism is the relationship with the candidate, politicians, campaign teams, and public officials. During this phase, journalists have proximity to the candidates, politicians, campaign teams and public officials, but despite following their activities, journalists who become Supervisory Committee (Panwas) are not writing a news product. Meanwhile, the way to refuse to write news on the campaign teams or politicians who already have a close relationship is by not going to their invitation and not covering the news.

In addition, to keep the news' independence, journalists avoid writing the news that potentially triggers conflicts or prone to rise problems in the future, such as arising lawsuits and others. Despite writing news on social, art and culture, if it is containing a conflict then it is avoided.

In selecting the language in writing news, journalists are preferred to use soft or refined language and not use a language that provokes certain parties. This is due to the journalist has a high motivation to report a topic or issue that is not in accordance with the rules such as corruption or other irregularities. When they have a motivation in facing the news of corruption, they often choose hard, frontal, or critical language in order to beat, disassemble or reveal cases such as corruption.

Another important restriction is that journalists are committed not to receive any kind of gift from anyone either from interviewee or public official, politician, campaign team or candidates. After becoming Supervisory Committee (Panwas), journalists put their journalism work as odd jobs or sideline. Meanwhile the main work is related to their duty as Supervisory Committee (Panwas). When they get sworn as Supervisory Committee (Panwas), journalists have been sworn and promised to work full time as Supervisory Committee (Panwas).

These restrictions are also performed by Sumali Ibnu Chamid, journalist of Radar Semarang who serves at Wonosobo Regency and currently a member of Wonosobo Regency Supervisory Committee in Central Java. He has become a member of Supervisory Committee (Panwas) since 2015, so he really understands how to run the profession of journalists along with Supervisory Committee (Panwas). The main restriction is he does not report or write politics news and only write news for socio-cultural and business economics. While the politics news is conducted by other respective teammates in the same media. Incidentally in Wonosobo there are three journalists of Radar Semarang, so that the political news is written by two other journalists. 
To keep independent, this journalist declares inactive from their respective journalist organization which they participated since 2008 namely Alliance of Independent Journalists (AJI) of Yogyakarta. This journalist is inactive from AJI of Yogyakarta since inaugurated as Supervisory Committee (Panwas) of Wonosobo Regency. Restrictions made by Habib Soleh, journalists of Suara Merdeka and member of Supervisory Committee (Panwas) of Magelang Regency are also conducted by Sumali Ibnu Chamid in conducting their duty of journalists and Supervisory Committee (Panwas) of Wonosobo regency.

Formation of Supervisory Committee (Panwas) is now regulated in the Law of 15/2011 of the election organizers. In that Law member of Supervisory Committee who concurrently becomes a journalist does not have to resign from the journalism. So that, now there are many journalists who become Supervisory Committee (Panwas) and work as a journalist for their media company. Beside Habib Soleh and Sumali Ibnu Chamid, there are some journalist who become Supervisory Committee (Panwas) in Central Java such as: Sugi Rusyono member of Supervisory Committee (Panwas) of Blora Regency, Amin Fauzi member of Supervisory Committee (Panwas) of Rembang Regency, Yon Daryono Chairman of supervisory Committee of Banyumas Regency, and Kustawa Esye Chairman of Supervisory Committee of Karanganyar Regency.

The restriction of journalists who concurrently become Supervisory Committee (Panwas) is illustrated as follows:

TABLE I

\begin{tabular}{|c|l|l|}
\hline No. & \multicolumn{1}{|c|}{ Restriction } & \multicolumn{1}{c|}{ Description } \\
\hline 1 & $\begin{array}{l}\text { Quantity or } \\
\text { Amount of News }\end{array}$ & $\begin{array}{l}\text { The amount of made news is reduced from } \\
\text { 3-4 per day becomes one news per day }\end{array}$ \\
\hline 2 & $\begin{array}{l}\text { Themes or } \\
\text { coverage area }\end{array}$ & $\begin{array}{l}\text { Field coverage other than political, include } \\
\text { social, cultural, and business economics }\end{array}$ \\
\hline 3 & $\begin{array}{l}\text { Relationship with } \\
\text { politicians, } \\
\text { candidates, public } \\
\text { officials }\end{array}$ & $\begin{array}{l}\text { As a journalist, he/she does not come and } \\
\text { write news when invited by politicians, } \\
\text { candidates, and public officials. }\end{array}$ \\
\hline 4 & $\begin{array}{l}\text { Journalism work } \\
\text { The work process of journalism is conducted } \\
\text { outside the duty of Supervisory Committee } \\
\text { (Panwas). E.g. conducted in the evening and } \\
\text { interview is conducted by phone. }\end{array}$ \\
\hline 6 & $\begin{array}{l}\text { News Language } \\
\text { Writing }\end{array}$ & $\begin{array}{l}\text { Language selection in news writing is more } \\
\text { subtle or soft language. Not using language } \\
\text { that tends to beat and attack yet provoke } \\
\text { conflict with certain parties }\end{array}$ \\
\hline 7 & $\begin{array}{l}\text { Journalist } \\
\text { Organization }\end{array}$ & $\begin{array}{l}\text { Committed to not receiving anything and } \\
\text { from anywhere over the work process of } \\
\text { journalists. }\end{array}$ \\
\hline
\end{tabular}

Considering the issues above, the researcher states that journalists who become Supervisory Committee (Panwas) in 2018 Central Java election has reconstructed their reality with their own limits in performing their profession as journalist. Based on the theory of social construction of reality, Berger and Lukman, a journalist is only the result of social construction through actions taken during their profession of journalist and Panwas 2018 Elections in Central Java.

\section{CONCLUSION}

The research indicates that the journalist independence who becomes Supervisory Committee (Panwas) at 2018 Regional Election in Central Java is only a result of construction through the action that is performed to make good restriction regarding the amount of made news and coverage field.

In keeping their independence, journalists strive to create the reality that they can run the duty as journalist and member of Supervisory Committee (Panwas) of 2018 Regional Election at Central Java by running it well, independently, impartially, neutral and professional. The effort is performed by limiting themselves not to perform journalism activities in the field of politics, law, and government as well as political. In addition, journalists also restrict the number of news, from 3-4 regular news per day, currently only as much as one news per day.

In addition, in conducting journalism activities they perform it mostly in the evening, meanwhile in the morning until afternoon they perform the duty as Supervisory Committee (Panwas). They are also committed not to accept bribes, or other gifts in any kind of form from the interviewees.

\section{VIII.RECOMMENDATIONS}

Result of research conducted on the journalist's independence as Supervisory Committee of Regional Election (Pilkada) in Central Java states that journalists in conducting the duties are vulnerable to the political interests, so that journalists find it difficult to maintain the independence of their journalism products. The efforts of journalists to restrict the journalism duty as part of the media is difficult. In addition, the journalists do not only conduct journalism duty on certain areas only. Based on that issue the researcher gives suggestion as follows:

- Press Council needs to be more assertive on the journalists who are also involved in organizing political event such as election. For example, requesting a retirement from the journalist profession.

- Organization of journalists (PWI, AJI, IJTI, and others) are required to discipline their members involved in the task of organizing political events such as Regional Election (Pilkada) by revoking the membership card from the organizations they participate.

- Media is expected to take decisive action by requesting a retirement of journalists who participate in elections because it will interfere their journalism product.

- Journalists who participate in organizing committee of regional election (Pilkada) is expected to resign from the profession of journalists. 


\section{REFERENCES}

[1] B. Kovach and T. Rosenstiel, Sembilan Elemen Jurnalisme [Nine Elements of Journalism]. Jakarta: Yayasan Pantau, 2001.

[2] A. Harsono, "Agama" Saya adalah Jurnalisme [My "Religion is Journalism]. Yogyakarta: Penerbit Kanisius, 2010.

[3] D. Mulyana, Metodologi Penelitian Kualitatif [Qualitative Research Methodology]. Bandung: PT. Remaja Rosdakarya, 2003.
[4] D. N. Hidayat, Paradigma dan Metodologi Penelitian Sosial Empirik Klasik [Paradigm and Methodology of Classical Empirical Social Research], Jakarta: Departemen Ilmu Komunikasi FISIP Universitas Indonesia, 2003.

[5] L. J. Moleong, Metodologi Penelitian Kualitatif Edisi Revisi [Qualitative Research Methodology, Revised Edition]. Bandung: PT. Remaja Rosdakarya, 2011.

[6] B. Bungin, Konstruksi Sosial Media Massa [Mass Media Social Construction]. Jakarta: Kencana Prenada Media Group, 2007. 